\title{
THE REFUGEE STATUS: CHALLENGE AND RESPONSE
}

\author{
RichaRd RobBINs*
}

I

No consideration of American immigration law today would be complete without some reference to that familiar type of immigrant-the refugee. The case for the refugee's inclusion requires no elaborate documentation. East and West, in Asia no less than Europe, wars, revolutions, and conflicts among nation-states have produced innumerable forced migrations. We have an indelible impression of these populations in flight, whatever the label selected to describe them-refugees, displaced persons, expellees, deportees, escapees. True, we Americans have been protected so far from actual population displacement, save those of us of Japanese descent who were victims of a policy of forced relocation during World War II. But we are conscious, nonetheless, of the refugee problem abroad, if only because we are continually weighing our tradition of asylum for victims of persecution against the realities of our basic immigration legislation now embodied in the McCarran-Walter Act. ${ }^{1}$

Definitions of refugees abound, some emphasizing the broad legal, moral, or sociological character of the problem, others the extent to which specific groups meet the test of refugee status. For want of space, we may hold to the brief definition utilized in Europe since World War II and recently incorporated, ambiguities intact, into the United Nations Convention on the Status of Refugees: the refugee is one who, "owing to well-founded fear of being persecuted for reasons of race, religion, nationality, membership in a particular social group or political opinion, is outside the country of his nationality and is unable or, owing to such fear, is unwilling to avail himself of the protection of that country." Although persons whose flight is internal within a nation-state, members of ethnic groups returned to a "mother country" after decades of separation, persons uprooted by famine and flood rather than by political fiat all know the condition of displacement too, they are not included in the United Nations' general definition. Without such fringe types, the

* B.A. 1946, Brooklyn College; M.A. 1948, Washington State College. Instructor in sociology and anthropology, Wellesley College. Studied various aspects of postwar refugee problems in western Europe under Fulbright grant, I949-50. Co-author [with Donald R. Taft], Internationst Migratrons (1955). Contributor of articles on immigrant and other minority group problems to various periodicals.

166 STAT. 163, 8 U. S. C. $\$ \$$ IIOI-503 (1952).

For the full text, see Jasies M. Read, Magna Carta for Refugees 25 (U. N. Pub. Sales No. 1953.I.33). On definitions for the interwar period, see John Hope Simpson, The Refuge Problem 4 (1939). On the legal problem, see Jacoues Vernant, The Refugee in the Postwar World 4-9 (1953). In Vernant's view, the legal status of the refugee is established when he has left the state of which he is a national as a result of political events and persecutions which transgress recognized moral principles. But how can consensus be reached among nations as to what constitutes a breach of moral principles? 
world-wide refugee population today is said to number about fifteen million; with the fringe types included, the figure jumps to about thirty million. These estimates are, of course, highly unreliable owing to continuous changes in the state of international tensions.

Neither the debate over definitions nor the disagreement over round numbers, however, constitutes the heart of the refugee matter. The crux of the problem lies rather in the complex relationship between the status of refugee and the status of immigrant. The striking aspect of refugee movements is their transitional character. Will refugees be offered the opportunity to achieve the more concrete status of immigrants, and after that, the ultimate status of citizen? What are the refugees' expectations of exchanging the unrewarding life of temporary camp communities for a permanent place in a viable community overseas? How are refugees, destined, faute de mieux, to settle permanently in the country which grants them temporary asylum, to find a solid niche in the social structure of that country? These are the questions of moment.

Only comparatively recently has the distinction between immigrant and refugee status become directly relevant to American immigration policy. Americans have usually been concerned not so much with separating the expelled from the voluntary immigrant, as with emphasizing the adjustment made by all kinds of newcomers to the American scene. If every schoolboy knew that many colonial settlers came to this country in flight from religious persecution in Europe, he knew equally well that the push-and-pull of economic conditions were also a factor. (What was often concealed from him was the ironic fact that the refugees from religious intolerance in the Old World frequently failed to practice tolerance of diversity in the New!) During the nineteenth century, the German refugee intellectuals from the revolution of 1848 mingled with the mainstream of German immigration; the Jewish victims of pogroms and the Jewish victims of poverty struggled together to build a new life on New York's lower East Side. After World War I, however, two fundamental changes occurred: in the United States, quota immigration-refugee or otherwisewas sharply reduced; but in Europe itself, refugee groups available for emigration were sharply increased as the new dictators began systematically to practice mass expulsion of "undesirables." The refugee question had then to be rephrased for Americans: how maintain over-all immigration restrictionism and, at the same time, make a place for some of the new refugees as a mark of our faith in the tradition of asylum to the oppressed? It is not in the least surprising that the "restrictionist thirties" witnessed the admission of some 200,000 refugees from German-controlled areas, a little over half of them Jewish-this at a time when public opinion polls showed two-thirds of the population opposed to an additional refugee influx, even - within the quota limits. ${ }^{3}$ The welfare organizations sponsoring the admissions did not feel they were in conflict with general immigration policy; they spoke rather of

\footnotetext{
${ }^{3}$ See The Fortune Quarterly Survey: XIIl, Fortune, July 1938, p. 36, at 80; The Fortune Survey: XX, Fortune, April r939, D. 84 at ro2.
} 
special emergencies and the urgent need to organize a rescue operation for Jewish and non-Jewish victims of Hitlerism.

When the termination of World War II confronted the Western Allies with another great mass of refugees and displaced persons, the American Congress took up anew the immigrant-refugee equation. There were those who argued that a restrictive policy had to be strictly maintained, refugees or no refugees. There were those in the middle who favored continuation of the national-origins quota system, but with allowance made for "emergency" refugee visas. And there was that small minority which urged a sweeping revision of the entire quota system, the end-result of which would be the assignment of "functional" priorities, regardless of place of origin, to dependents, workers with special skills, and refugees meriting asylum. ${ }^{4}$

Over the last decade, Congress has pursued, as one might have expected, a compromise course. While the quota system has been maintained intact, a series of dispensations have been made for refugees. So long as sentiment supported participation by the United States in the international approach to the refugee problem, congressional intent could be translated into reasonably effective legislation. Under the Displaced Persons Act, ${ }^{5}$ about 400,000 displaced persons entered this country on special quota visas, ${ }^{6}$ though Congress maintained a restrictionist hold on the operation by developing a novel "mortgaging" system." Today, however, the patchwork solution is increasingly self-defeating; the effort to match regular immigrants, "surplus peoples," and refugees with the various national quotas has met with only fair success. The bumbling provisions of the Refugee Relief Act of $1953^{8}$ are traceable not simply to the guile of individuals, as charged by such critics as Edward Corsi, but to congressional reluctance to face up to the immigrant-refugee relationship. ${ }^{\theta}$ 'The way to proceed would appear to be to develop an immigration policy flexible enough to cope with the periodic refugee emergencies within the framework of a general admissions system. The way not to proceed would appear to be to continue to pass special refugee legislation either wholly at odds with the regular admission system or haphazardly attached to it.

\footnotetext{
'See generally Hearings before the President's Commission on Immigration and Naturalization, 82d Cong., $2 \mathrm{~d}$ Sess. (1952). The last proposal was advanced by the Commission in its report, Whom We Shall Welcome xr7-23 (1953), and was incorporated in a bill introduced by Senator Lehman (D., N. Y.) in 1955. S. 1206, 84th Cong., Ist Sess. (1955).

¿62 Stat. Ioog (1948), as amended, 50 App. U. S. C. $\$ \$ 1951-63$ (I952).

${ }^{\circ}$ See U. S. Displaced Persons Comm'n, The DP Story 77-83 (1952).

${ }^{7} 62$ Stat. Ioro (1948), as amended, 50 App. U. S. C. $\S 1952$ (c) (1952). Up to one half of the visas assigned to displaced persons from small countries-which had exhausted their regular quotas-were, by virtue of this provision, charged against future quotas; future regular immigrants thus "paid for" present refugee immigrants.

${ }^{8} 67$ STAT. 400, as amended, 50 App. U. S. C. A. $\$$ I97I (Supp. 1955).

'On the strange "affaire Corsi" and the administration's unwillingness to further its own refugee legislation, see Edward Corsi, My Ninety Days in Washington, in The Reporter Reader 34 (Max Ascoli cd. 1956). It would appear that the Eisenhower administration obtained its weak refugee law only by pledging to ignore altogether the larger and related question of a revised immigration policy. The refugee law was aimed at placating the liberal welfare organizations, on the one hand, without antagonizing powerful restrictionist sentiment in Congress, on the other. On these matters, see Rorty, Our Broken Promises to the Refugees, 20 Commentary 30r (I955).
} 


\section{II}

Over and above American immigration policy, what are the images evoked by these two status categories, immigrant and refugee? Conditions differ so markedly according to region and type of ethnic group involved that any simple set of distinctions is bound to be unsatisfactory. Nevertheless, some rudimentary distinctions may be drawn. Fundamentally, the refugee's status is that of "victim of persecution." He belongs to a group violently uprooted by war or state decree. He is temporarily homeless, the word "temporary" importing several months or possibly several years. His ultimate destination is uncertain. He is likely to show greater psychological strain than is common among traditional economic migrants. And as a kind of ethical compensation for the tenuous quality of his status, he has a legitimate moral claim upon host state or international community for legal protection, social assistance, perhaps overseas resettlement.

Once arrived in a country of reception, however, the refugee is at the threshold of status transition. He is, henceforward, the immigrant from abroad seeking permanent residence. His distinguishing mark, like that of the immigrant, is national culture difference, though his status as a victim of persecution or his ethnic ties with the host population may mitigate somewhat the most serious clashes of culture. With the economic migrant, he takes his place in the domestic labor force, hoping for parity with other foreigners in the quest for employment. It is natural that as public awareness of the refugee's painful experience begins to fade, his socioeconomic status should approach that of other foreigners. Legally, the refugee now assumes the status of resident alien, unless he is fortunate enough to gain immediate acceptance as citizen in the new homeland. In the United States, the transition in legal status does not seem a matter of pressing importance; once arrived, the refugee is, in principle, the same kind of resident alien as the regular immigrant. In the Old World, however, the sequence refugee-to resident alien-to citizen is not always an orderly one. It is not uncommon for the refugee-alien to face unexpected crises over his passport, to find himself without adequate legal protection, to be suddenly detained as a candidate for expulsion (refoulement). ${ }^{10}$

There is, then, a continuing and involved relationship between the status of refugee and that of immigrant. The two categories seem most divergent at the source of emigration and during the voyage between countries. Then the refugee's situation is the more chaotic, his outlook the more bleak. This is especially so where the refugee is also legally stateless-that is, when no government recognizes his legal claim to citizenship. Not that the modern economic immigrant is altogether free of problems; he, too, must suffer a sea-change in transferring from one culture to another. But in his case, a degree of order and purpose prevails-he has left a definite place behind, he looks ahead to a specific community, and if trouble ensues, he can obtain the legal protection of his consul. In any event, however, by the time the terminal point of the migration is reached and refugees and immigrants

\footnotetext{
${ }^{10}$ See Simpson, op. cit. supra note 2, for many examples.
} 
have won admission to countries of reception, the status distinctions begin to disappear. As we have seen, the American emphasis is on the absorption of refugees into the body of general immigrants, who assume status positions according to race, color, religion, or national culture. Elsewhere, however, refugees may undergo continued persecution in the host countries while other types of immigrants escape discriminatory treatment. Or they may remain marginal to the community, sharing in the new culture but hoping for a change in political climate that would permit their return to their countries of origin: thus, the Spanish refugees in Mexico, readily absorbed into Mexican culture yet not of it. Conversely, that small band, the elite refugee artists and scholars, may win acceptance abroad as symbols of the need to preserve creative intelligence from the blight of dictatorship: thus, Einstein's science and Casal's musical art, as against the Hitlers and Francos of Europe. Again, refugee groups may be found in a sort of social limbo, expelled by one country, unwanted by the countries to which they flee: thus, the Arab refugees in West Jordan. It is obvious that the determination of final status for refugees is dependent upon a great many factors, and the list of examples presented does not begin to exhaust the number of possibilities for status transition.

In an era of great social instability, chance and fortuitous circumstances must be considered important elements in determining the refugee-immigrant relation. A concrete example serves better than a general discussion: The German-Jewish refugees who came to the United States on the eve of World War II were able, in the main, to bypass many obstacles encountered by regular immigrants. A middleclass background, a comparatively wide range of occupational skills, educational advantages, a determination to cut ties permanently with Germany, and a strong measure of support from American Jews and non-Jewish liberals-all aided the group to make a sound, diversified adjustment to American life. ${ }^{11}$ If there was some dissatisfaction among the refugees over downgrading in socioeconomic status and some tendency among Americans in contact with the refugees to stereotype from unfavorable individual experience (giving rise to the image of "ungrateful" or "arrogant" refugee), the German-Jewish group moved steadily, nonetheless, from refugee status, to resident alien status, to citizenship. By way of contrast, GermanJewish refugees caught in France on the eve of World War II and unable to remigrate discovered that in the country of asylum par excellence, xenophobia had reached a point where one's status as refugee only complicated an uncertain position as German and Jew. The downward path led from the anti-Semitic, police-state practices of the Daladier regime to detention and deportation during the Occupation. $^{12}$ Of course, this is only an illustration; it does not purport to stand as an index to the traditions of asylum in France or the United States.

The parallels and contrasts drawn above, however, still do not provide a clear,

11 See Maurice Davie, Refugees in America cc. 9, yo (1947).

${ }^{12}$ See generally Abbe A. Glassberg, A ra Recherche d'une Patrie; La France devant im'ImmigraTION (I946). 
succinct, and satisfying answer to the question: what is the special distinctiveness of the refugee status? Reverting to our earlier description of an abstract refugee status, three working generalizations, qualified, once again, as to time and place, are suggested: First, it seems indisputable that social disorganization is both more extensive and more intense among refugees than among immigrants. Second, the very fact that the refugees' condition brings with it great social and psychological strain makes it all the more probable that a response to their plight will be evoked among peoples not directly affected by the refugee problem themselves, but conscious of its tragic dimensions. In considerable measure, that response can be termed ethical or moral in character. And third, when the desire to come to the assistance of refugees is translated into actual policy, it is likely most effectively to be realized if guided by an international organization empowered to seek commitments from member nation-states. These general aspects of the refugee problem warrant brief appraisal before attention is turned to specific refugee groups in various regions of the world.

No one has portrayed more incisively the scope of social disorganization among European refugees than has Hannah Arendt in her recent work on the growth of totalitarian systems. She holds that the price we pay for an increasingly rigid nationalism is measured both by the greater number of persons expelled from one state and by the reluctance of other states to grant the expellees refuge and safety. As a result, "whoever was thrown out of one of these tightly organized closed communities found himself thrown out of the family of nations altogether."13

In other words, disorganization means loss of identification with one's social community, not merely disruption of one's life inside the community. This decription of refugees and stateless persons, caught, as it were, in a no-man's land between communities, suggests a Kafka-like social disorder. Of course, so sweeping and forbidding an indictment needs qualification. There is evidence that the psychological impact of "displacement shock" is very variable among different refugee families. $^{14}$ Indeed, some refugee groups display a surprising resiliency, a strong desire to recreate a primary group existence similar to that achieved before dis. placement, and this persists even in the detention camps which epitomize Arendt's thesis. ${ }^{15}$ Yet, even with these reservations, the refugee problem in both Europe and Asia still remains a telling example of how far we can be carried from the fundamental principle that men stand in need of an organized social community so that they may assert, paradoxically, their very uniqueness and individuality.

If this were all, then the refugee plight would be one of unrelieved gloom. There would be widespread disorganization, in Arendt's terms, and no reorganiza-

${ }^{13}$ Hannah Arendt, The Origins of Totalitarianisa 291 (I95I).

14 There arc many moving descriptions of "displacement shock" and severe social disorganization among refugees, but few structured psychological studies. For some examples of the latter, sec H. B. M. Murphy, Flight and Resettlemient (1955).

${ }^{15}$ See, e.g., Leo Schwar7, The Redeemers (1953); Katherine Hulme, The Wild Place (1953); Riesman, Some Observations on the Limits of Totalitarian Power, 12 ANTIOch Rev. 155 (1952). 
tion. But a countervailing force is present, waiting to be developed. To repeat our second general proposition: the great social disorganization involved in mass expulsion can-not must-stimulate a correspondingly greater measure of assistance from peoples in the more distant, safe communities. Assistance springs, in considerable degree, from a sense of moral compassion, the expression of which is the counterpart of the refugee's status as victim of persecution. Here is a sort of international ethic, whether secular or religious, a modern version of the ancient tradition of asylum. It eventuates in sponsorship of emergency relief, in support for refugee rehabilitation projects abroad, or, most significantly, in revisions of immigration laws sufficient to permit some of the refugees to gain admission to one's own country. No amount of shallow sociological theory about the relativism of ethical codes in the West, no contention that discussion of the moral element is but an unsupported "value judgment," can obscure the ethical aspects of the refugee problem.

This is not to say that the ethical obligation felt among populations not directly touched by the refugee plight is a simple, clear-cut matter. On the contrary, the moral factor is complex, diffuse, and often subordinated to other considerations. The status of the refugee as victim of persecution is the stimulus for the work of such organizations as the American Friends Service Committee or the Catholic agency Caritas, to whom the problem is primarily ethical. But it must be remembered that the refugee can also present himself as an immigrant seeking admission to a country whose people are concerned more with their own employment situation than with intricate ethical questions. Moreover, the moral factor is always worked into an institutional setting, so that the refugee question is meshed with the debate over political and economic policy. If the necessity to "help alleviate suffering overseas" is "sold" to the domestic policy-making body on the basis of "filling gaps in our labor supply" or "striking a blow at communism," its presence may yet be acknowledged. In an abstract way, everyone is for asylum to refugees, as everyone is against sin, but policy formation, even in the best of all possible democratic societies, is a matter of shades of gray, and ethical impulses are as subject as any other to the conflicts and compromises of the political process. It should be added that the moral factor is equally complicated on the refugee side. Many refugees do not want to be viewed solely as victims of persecution, in need of "international charity." They aspire, and rightly so, to the more meaningful status of immigrant in a new country, where opportunities for work and family security are mingled realistically with the usual obstacles to immigrant adjustment. But even when the issue of persecution is paramount, refugees are not thereby stripped of all their other values, attitudes, and social backgrounds. Some refugees, for example, are too old to fit into the labor force effectively; and, as victims of persecution, although they have the sympathy of governments overseas, they are not wanted as immigrants. It happens, too, that refugee groups can be narrow and chauvinistic in their outlook, however logical the assumption that as victims of intolerance, they ought to strengthen their bonds with other abused minority groups. 
A moral issue is probably posed most forcefully along these lines when the refugee group seeking assistance is presumed to be accountable, in some way, for the mass expulsion of other groups in the past, whether by active deed or by acquiescence in a government's policy. The obvious case is that of the German ethnic minorities (Volksdeutsche) and Germans from territory taken over by Poland (Reichsdeutsche), who were driven into rump Germany by East European governments at the close of World War II. They had an authentic refugee status; they endured extreme social disorganization; they needed international assistance. But these were enemy people, "associated" both with the Nazi program of internal subversion of governments, and with the deportation and massacre of non-German peoples. Did the United Nations countries, which had suffered years of Nazi exploitation, have a moral obligation to support these refugee groups? Or was it simply a matter of do unto others...? The answer to the question had to be of mixed character. As enemy people, the German refugees did not come under the United Nations mandate; they were supported directly by the West German government and private welfare agencies. But the Allied powers contributed massive sums to the restoration of the West German economy and social structure, which greatly facilitated the task of refugee absorption. And the American Government authorized the admission of 54,000 Volksdeutsche under the terms of the Displaced Persons Act. ${ }^{16}$ On the other hand, the postwar Czechoslovakian Government, having experienced subversion on the part of its German minority, expelled the entire Sudetan group, the apolitical along with the active Nazis and traitors. If President Benes' resolution of the moral dilemma was understandable, it was also certainly unwise; mass expulsion in retaliation for mass expulsion only creates greater social disorganization. ${ }^{17}$

With all the grave difficulties in arriving at consensus as to what is ethically right or wrong in establishing policy toward uprooted peoples, it still seems reasonable to assert that the refugee problem generally structures a set of moral choices. ${ }^{18}$

${ }^{16} 64$ StAT. 226 (1950), 50 App. U. S. C. $\$$ 196I (1952), amending 62 STAT. 1013 (1948).

${ }^{17}$ Retaliation in kind represents, as well, a breach of moral principles in the sense meant by Vernant. Anti-Nazi countries are placed in the uneasy position of defending policies against which they had earlier waged unceasing war. To some degree, the view that "the whole German population is responsible for Hitler" echoes the Nazi racist view that "the whole non-German population is racially inferior." On this problem, see Donald R. Taft and Ruchard Robbins, International Migrations 246-47 (1955).

${ }^{18}$ There is an interesting parallel here between the international refugee problem and the American Negro problem, defined as a "moral dilemma." Sce Gunnar Myrdal, The American Dilemma 3-25 (1945). The American Creed, Myrdal observes, with its emphasis on equality of opportunity, stands in opposition to discrimination against Negroes, South and North. Similarly, there is tension between an "international creed," based on asylum for the displaced, and the reality of restrictive immigration policies and hostility to refugees. However, the analogy should not be pursued too far. In the first place, "moral dilemma" is not an adequate explanatory framework. As has been noted, anxiety about ethical contradictions need not result at all in group activity, in policy formation. Myrdal's premise, employed in oversimplified fashion by others, leads to an evasion of the prime fact that the uses and abuses of power give direction to ethical impulses. Diffuse ethical creeds gain sacial force in being submitted to the exercise of power by legislatures, business groups, unions, courts, and burcaucracics. More to the point here is the difference between population displacement across national boundaries and a race problem within a state. The context for "moral dilemma" differs accordingly. The improvement in the Negro's lot takes place inside a viable social community; no one takes seriously proposals for a mass Negro exodus to Africa, or even a total population transfer from South to North. But the 
We feel a certain responsibility toward the victims of political persecution or wartime displacement; this is an important element, if not the only one, in the programs developed to assist refugees and displaced persons.

What form should the assistance take? Where is the balance to be struck between national interest and international obligation? Our third generalization is germane here. Countries of potential reception have been turning from unilateral policy and from bilateral agreements to multilateral arrangements governed by an international organization. And many refugees themselves, having lost their rights in one community without gaining protection and asylum from another, have also become more dependent on international organization, on the "Geneva community." Host countries look to the international organization because it can manage a complex many-sided operation effectively; refugees look to the international community because there may be no other.

The international organizations formed to cope with the refugee problem have open to them a limited range of policies. Where feasible, they encourage repatriation, a necessary course of action at the close of a war when thousands desire nothing more than a swift return to home, but at other times, acceptable to the western democracies only on a voluntary basis. For those who fear to, or are unwilling to return, the international organization sponsors a relief program-food, shelter, clothing, medical service. Essential as relief is during an emergency period, there is no doubt that if it is prolonged beyond several months and is unaccompanied by programs aimed at employing refugees in jobs outside the camps, the result is serious debilitation in the camp population in both a material and psychological sense. (The recent controversy over the Baghdad Pact was but a pretext for the Arab refugees in Jordan to engage in aimless rioting and destruction.) A more positive approach is summed up in the word reintegration-or, more simply, integration. The international organization aids the refugee in making a permanent adjustment in the country of first and temporary asylum. In plainer language, this means that both host country and international agency recognize that a given refugee group cannot go back, nor can it go forward. The realistic policy is, therefore, to make plans for legal protection, self-sustaining employment, and welfare assistance in the country of first residence, thus moving the refugee group off the dole. But often the alternative of settling permanently in the country of first residence is not open to the refugee group for various reasons. Then, the international agency may assume responsibility for resettlement, an organized emigration of refugees from the unstable territory of first asylum to more stable nation-states, frequently overseas. When resettlement suc-

refugee's uneasy position between communities means that he is cut off from those groups in the community which command the power to make his protest heard. For the refugee, there is no NAACP; hence, his dependence on an international organization for legal protection and assistance. Such is the European pattern. In the United States, however, when the refugee has become the immigrant, the "New American," he is generally able to make a steady progression in status, so that over two or three gencrations, he will have moved far toward full participation in the community. Ironically, the Negro, one of the earliest among the "Old Americans," is held back from a similar transition by skin-color status. 
ceeds, the opportunity is made available for refugees to make the familiar transition to immigrant, resident alien, and citizenship status in a more promising social setting.

In the period between the wars in Europe, international assistance was usually limited to relief and reintegration, if not to simple legal protection alone. Resettlement never came under consideration. Even in their limited aspirations, the refugee organizations were largely ineffective. The rising tide of refugees, the low prestige of the League of Nations, to which most of the refugee organizations were attached, and the intransigence of the new totalitarian regimes engaged in mass expulsion resulted in the enfeeblement of the international approach. If they were less than overwhelmingly successful, however, the interwar agencies performed a valuable service in setting the precedent for the more ambitious multilateral programs in behalf of refugees developed after World War $\mathrm{II}^{19}$ Thus, the International Refugee Organization (IRO) was able to resettle more than a million refugees and displaced persons between 1948 and 1952 , a feat described by the organization's last director-with a touch of prideful overstatement-as "the most successful and the most efficient example of large-scale international cooperation in history." ${ }^{20}$ It is now axiomatic that where large numbers of people have been displaced and are not settled in ethnically homogeneous territories, any long-range program in their behalf should be supported through an international organization, preferably within the United Nations. And for the displaced person, especially if he is legally stateless, the presence of an international agency implies assurance of a minimal legal and social status.

In sum, the refugee problem is bound up in considerations of status transition, social disorganization, moral decisions, and international cooperation. But the problem is, in fact, many problems-as will be seen.

\section{III}

A glance at Table $I$ indicates that while the largest numbers of refugees are found in Asia and the Middle East, the international response to their distressed

${ }^{10}$ The important interwar agencies were: the League of Nations High Commission for Refugces (1921-33), whose mandate covered mostly White Russians and Armenians; the Nansen International Office for Refugees (r933-38), which developed the initial Refugee Convention providing refugees with travel documents, legal protection, and minimal social assistance; the High Commission for Refugecs Coming from Germany (1933-38), totally ineffective in the face of Nazi power; the High Commission of the League of Nations for Refugees (1938-47), an over-all agency which administered the conventions and sponsored very limited reintegration programs for about 500,000 persons; and the Intergovernmental Committee for Refugees (1938-47), formed outside the faltering League structure on the initiative of President Roosevelt, but rendered virtually ineffective by the outbreak of World War II. For more detailed analysis and description, see generally Simpson, op. cit. supra note 2.

${ }^{20} \mathrm{~J}$. Donald Kingsley, speech in Geneva marking the embarkation for resettlement of the millionth IRO refugee, October I95I. IRO's constitution came into force in 1948. It had a membership of eighteen nation-states and spent over $\$ 400,000,000$ in behalf of refugees in four years, with the United States contributing more than half of the costs. In addition to the 400,000 resettled in the United States, there were about 125,000 sent to Canada, about 130,000 to Israel, nearly 200,000 to Australia, about 90,000 to England, and smaller groups to Latin America, Scandinavia, and scattered points in Africa. The complete account is contained in Rene Ristelhueber, Au Secours des Refugtes; i'Oeuvre DE I'OIR (I95I). 


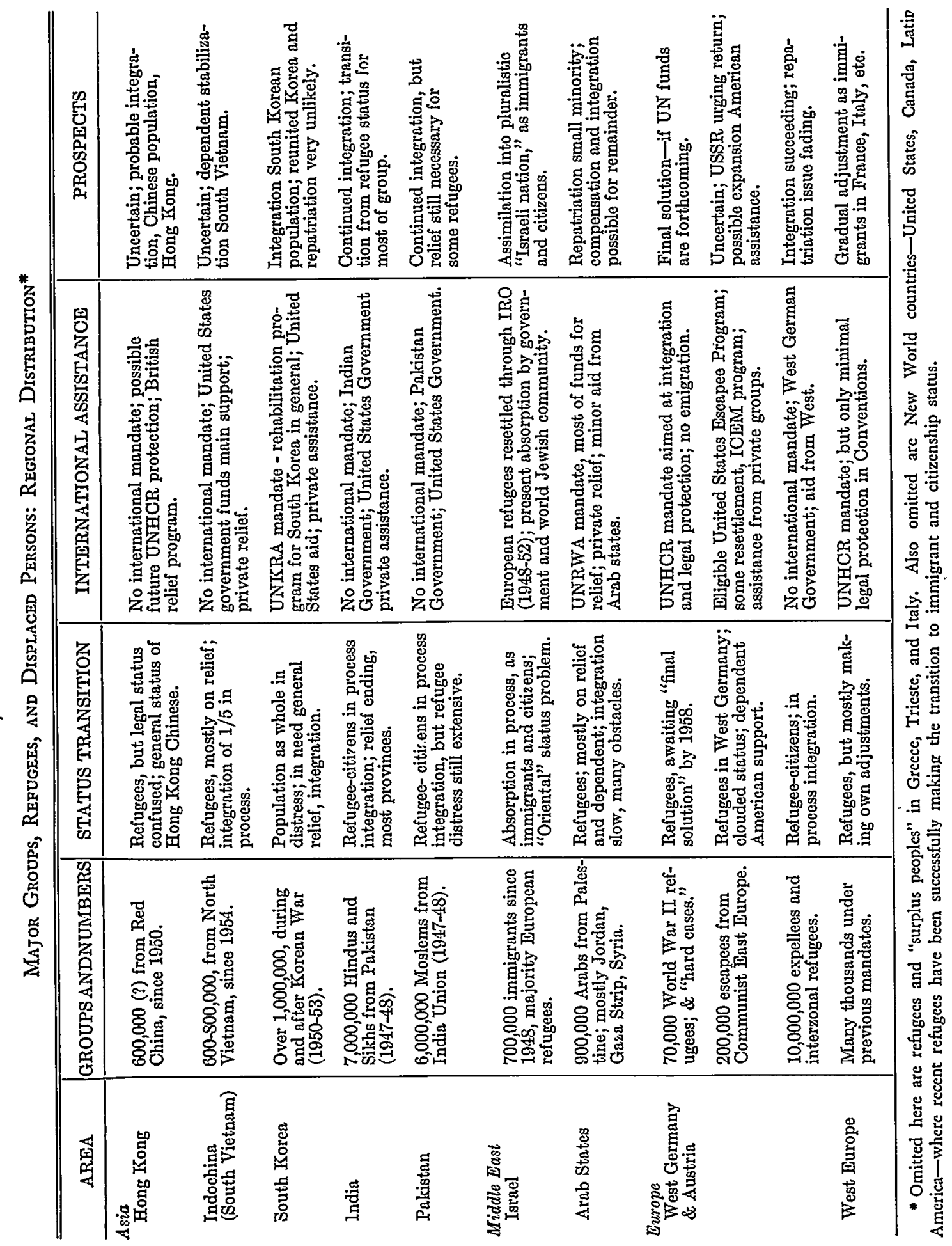


condition has been limited in scope. In particular, overseas resettlement has been applied on a considerable scale to the European refugee problem, not at all to the Asian and Middle Eastern situation. The reasons for this apparent contradiction of our general thesis are not hard to discover. These latter countries, with the exception of Israel, are characterized by large populations, comparatively low living standards, village-peasant economies, and a lack of higher occupational skills. Increasing birthrates, while the death rate continues to fall, promise accelerated demographic growth-at least until that distant time when industrialization may provide various restraints. Governments, hard-pressed to find resources to sustain the general population, are ill-equipped to deal with a large-scale refugee influx, beyond providing minimal relief. In some countries, official corruption and spoliation of the treasury by a feudal ruling class further inhibit assistance from flowing to the refugees. The paucity of high labor skills among the refugees would prevent overseas emigration to the West, even if rigid racial restrictions were not imposed. One result of all this is that status distinctions between peasants and peasant-refugees are soon blurred. Another is that a large measure of whatever special support goes to refugees is dependent upon action by the West. But the very size and complexity of the refugee problem in Asia and the Middle East-as compared to Europe, where United Nations agencies speak of "final solutions"-place limits on what the western powers are able and willing to contribute. In short, both the countries concerned and the Euroamerican community in a position to assist them are constrained to confine their activities to encouragement of voluntary repatriation, or to limited programs of relief and reintegration. Even if the irrational color bar against these "darker races" were not at issue, overseas resettlement of a few thousand refugees would have little utility, since populations would continue to grow very rapidly.

The West is recognizing the need, however, for token emigration of both regular and refugee groups from Asia and the Near East. Australia's "white only" policy is now relaxed to the extent of admitting several hundred Asian students on temporary visas, and their reception has been favorable. ${ }^{21}$ The United States virtually ended the Oriental's racial exclusion and ineligibility for citizenship in 1952, granting minimal quotas to countries whose members were formerly completely excluded. ${ }^{22}$ Our recent Refugee Relief Act of 1953 , too, makes a place for a few Korean, Chinese, and Arab refugees. ${ }^{23}$ There is no reason why token immigration of this sort could not be increased over the present microscopic level. Indeed, it should be. But the effect would remain chiefly symbolic.

When we turn to actual refugee groups, these considerations are given greater force. For example, there are about 600,000 "white Chinese" refugees at the present time in British Hong Kong. Unwilling to return to Red China, they are crowded

\footnotetext{
${ }^{21}$ See N. Y. Times, Dec. 27, 1955, p. 3, col. $x$.

${ }^{22} 66$ STAT. I75, 8 U. S. C. \$ II5I (1952).

${ }^{23} 67$ Stat. 401, as amended, 50 App. U. S. C. A. $\$$ I971(b)(11), (12), (13), (14) (Supp. 1955).
} 
into an area of only 365 square miles. They range in status from wealthy businessmen who have built new enterprises in the colony to the most destitute ("squatters") in the transient shoreline slums. In between are thousands of petty traders eking out a living in a city whose function as a commercial link between China and the West is hampered by ideological conflict. While Hong Kong is ninety per cent Chinese, there is little social cohesion between permanent residents and refugees. Nor is there an international organization to remedy the lack of support from Chinese; in I954, on the basis of a study by a distinguished student of international law, the United Nations' High Commissioner for Refugees decided that the Hong Kong refugees did not come under its mandate. ${ }^{24}$ (The problem stemmed from the complex legal relationship between Red China, Nationalist China, Britain, the United States, and the United Nations.) Pending an expansion of the High Commissioner's mandate, the outlook for this group of refugees is for gradual integration into the colony's Chinese population, with small-scale relief forthcoming from the British Government. Resettlement is not at issue, since the refugees have no desire to migrate to Formosa and since Southeast Asian countries, struggling to devise a formula for dealing with the "dual nationality" of their Chinese minorities, have placed strict limits on additional Chinese immigration. ${ }^{25}$

In Indochina, the Geneva truce (I954) sanctioned the division of the former French colony into North Vietnam, controlled by the Vietminh Communists, and South Vietnam, supported by the free world. Since partition, about 600-800,000 refugees, the majority Roman Catholic, have fled to the South. ${ }^{26}$ Other groups within the southern sector were displaced by the long, bloody war. The refugees are living under very distressed conditions, with assistance confined largely to American relief, public and private. The refugees do not receive minimal legal protection from the UN. Even the relief program is seriously curtailed because of corrupt practices by public officials in the Diem government. In 1956 , the Diem government finally completed plans for integrating about 100,000 refugees by settling them on abandoned ricelands in the Southwest. Most of the expenses will be borne by the American Government. The project's success depends upon factors far removed from the refugee situation: decisions on countrywide elections, Communist penetration, the ability of the Diem government to maintain order. The first efforts to move the refugee problem from relief to reintegration could readily succumb to further disorder.

Korea is similarly truncated, a Communist-controlled government above the $3^{8 \text { th }}$ parallel, a government sustained by the free world below the line. The territorial division, maintained after World War II and restored after the Korean War

2t Dr. Edvard Hambro's full report is still unpublished, but the preliminary findings were released in March 1955. See, for the aims of the study, High Commissioner for Refugees, Report, U. N. General Assenrbly OfF. Rec., Ioth Sess., Supp. No. II (Doc. No. A/2902) (1955).

${ }^{25}$ See Mallory, Chinese Minorities in Southeast Asia, 34 Foreign Afr. 258 (1956).

"See Exodus: A Report on a Voluntary Mass Flight to Freedom, Vietnam, 1954, 32 Dep'T State BuLL. 222 (I955). 
armistice, is certain to persist for some time. It might be translated from geographical into ideological terms, as a contrast between totalitarianism and democracy, were it not for the embarrassing fact that Syngman Rhee's South Korean regime verges on the dictatorial itself. Nevertheless, the existence of thousands of refugees from the North indicates that it would be sophistry to so equate the two Koreas. Moreover, the onus for armed aggression rests squarely with the North Korean and Chinese Communists.

Nothing more clearly illustrates our generalizations on social disorganization, moral dilemma, and international cooperation than does the Korean refugee situation. Thirty-seven months of war devastated South Korea; casualties were nearly half a million, cities were leveled, economic capacity was destroyed. So widespread was the destruction and disorganization that refugees from the North and residents engulfed by the war in the South could not be clearly distinguished. The United Nations member-states, with the exception of the Soviet Union and its satellites, responded to Communist aggression in defiance of the United Nations Charter by mounting a military counter-offensive, the United States bearing the brunt of the military burden. Without arguing whether "justified wars" can be nicely distinguished from "unjustified wars," it can be asserted that in this case, when the problem had passed to the level of outright force, the United Nations did acknowledge a moral obligation to deal with aggression. And, by the same token, as international cooperation had been employed to protect Korea, so it had to become the prerequisite for rebuilding Korea. The United Nations Korean Reconstruction Agency (UNKRA) commenced to fulfill this function when hostilities ceased in 1953. It had no special mandate for refugees; the basic task lay in rehabilitating the Korean socioeconomic structure, to the benefit of refugee and nonrefugee. (Refugee orphans did have a special status, and some became eligible for overseas resettlement, but they were a relatively small group.) UNKRA's results, to date, have fallen short of its generous goal, principally because member-governments have not met their financial commitments, but also because of the sheer magnitude of the task, local corruption, and complications inherent in a country economically divided in two. Against these obstacles, however, UNKRA has made a notable contribution to the idea of internationally planned reconstruction in industry, health, education, and social welfare. ${ }^{27}$ Relief is slowly giving way to reintegration. Neither repatriation nor overseas resettlement are viable alternatives.

India and Pakistan also owe their refugee problems to partition. With freedom from Britain achieved, neither the Hindu majority nor the Moslem minority could unite under the flag of a single, pluralistic state. The social disorganization attendant upon independence was followed by intense religious communal strife and then by an unplanned, chaotic cross-migration. About five or six million Moslems are reported to have fled to Pakistan from the India Union, while close to seven million

\footnotetext{
${ }^{27}$ See Korean Reconstruction Agency, Report of the Agent General, U. N. General Assembly Opp. Rec., 9th Sess., Supp. No. 20 (Doc. No. A/2750) (1954).
} 
Hindus and Sikhs entered India from Pakistan. The cost was high in deaths, rape, arson, and property damage. The transfer did not produce a final solution; sizable religious minorities remain in each country. In an era when social disorganization is a common phenomenon, this migration stands as a special case. "The memory of senseless and brutal bloodshed will possibly remain a permanent source of resentment between the two countries." 28

Today, nearly a decade after these events, reintegration is proceeding in both countries, but more successfully in India than in Pakistan. The two governments were confronted with a refugee problem over and above the usual challenges common to heavily populated countries. All the more striking, then, is the vigor with which the Indian Government has eliminated most of the relief camps, built model towns, and made land grants and loans to its new citizens-by-migration. The refugee situation has not been regarded as an international responsibility, nor, for obvious reasons, has it been linked to overseas resettlement, but benefits have flowed indirectly to refugees from the technical assistance programs of the United States and the United Nations, programs designed to stimulate Indian development at the village level. While it would be untrue to say that a "final solution" has been reached, it is safe to predict that within the next decade, refugees will be sharing with lifelong residents the new economic opportunities as well as the traditional conditions of poverty and communal strife. The refugee problem will be absorbed into the broader themes: population increase, urbanization, industrialization, land reform, labor out-migration to Ceylon and other countries. In Pakistan, however, reintegration programs for the refugees have not been as successful; social misery is widespread, and short-run relief still necessary. Pakistan does not possess India's economic resources, and it seems to be more resistant to socioeconomic change. This is to say nothing of Pakistan's handicap in being composed of two distinct territories, separated by hundreds of miles. Even so, the direction of change is similar to that in India. ${ }^{29}$

What forcefully strikes the observer in the Middle East is the great difference in status between the Arab refugees and the refugee-immigrants in Israel. Israel's Jewish refugees are moving toward absorption into a viable community, whatever the accompanying strains. ${ }^{30}$ The Arab refugees have fled their Palestinian homeland without winning acceptance in neighboring host states where their "Arab brothers" are found, and they are bitter and disillusioned. ${ }^{31}$

In 1948, Arab leadership brought the refugee problem upon itself. With the state of Israel established under the aegis of the United Nations, Arab armies were plunged recklessly into a thoughtless war whose consequences were resounding

${ }^{28}$ Kingsley Davis, The Population of India and Pakistan izi (x95I).

${ }^{20}$ See Samuels, On the World's Conscience, N. Y. Times Magazine, Jan. I6, I955, p. I3, col. I.

${ }^{30}$ Sce generally, e.g., Raphael Patar, Israel Between East and West (I953); S. N. Eisenstadt, The Absorption of Immigrants (1954); Norman Bentwich, Israel (1953); 57 Am. Jewish Y. B. (1956).

${ }^{31}$ See, e.g., How the United Nations Helps the Palestinian Refugees, 2 U. N. Rev. I I (1955). 
defeat and a mass exodus of Palestinian Arabs. By 1956, however, the "moral case" is so confused that neither the Jews, the Arabs, nor "Perfidious Albion" can be charged with all the "blame" for the crisis and all the responsibility for breaking the impasse. Officially, Arab spokesmen argue that the only course is repatriation of the entire 900,000 refugees-500,000 from Jordan, 200,000 from the Gaza Strip, and roo,000 from Syria and Lebanon, respectively-a manifest impossibility. On the other side, Israel appears to have withdrawn its earlier offer to repatriate up to I00,000 and to compensate those remaining from its own funds and with assistance from the West. Vicious Israeli border raids, deserving the United Nations' censure, are more than matched by Arab pillage of Jewish border settlements. The disheartening aspects of the new Jewish nationalism must be considered against the background of Arab feudalism, with millions in oil revenues wasted by a privileged elite. $^{32}$ And Soviet arms, sold to Egypt and other Arab countries, also reduce prospects of compromise.

Meanwhile, of the Arab refugees who are on the rolls, about forty per cent are actually in camps, with others billeted in crowded villages. Their status is the unenviable one of men on relief, dependent on international aid for food and shelter. Their daily food ration is adequate, if meager; indeed, in this respect, their condition is not far below that of the poverty-ridden nonrefugee fellahin. Even so, the lot of the refugees is not a happy one. They are said to long for repatriation to the last man, but no one really knows their attitudes. They receive the social security of the ration card, but require something more-employment and integration into a community. The United Nations Relief and Works Agency for Palestine Refugees (UNRWA) spends about $\$ 25,000,000$ annually for refugee relief, but UNRWA's $\$ 200,000,000$ available for integration projects is only beginning to be used, as Arab resistance to the projects declines to some degree. ${ }^{33}$

UNRWA has long recognized the necessity of moving refugees "from ration lines to self-supporting employment, and to make them economic assets of the near eastern countries."34 Its aim has been to reduce relief to the extent that integration projects succeed. Unfortunately, the numbers made self-supporting through I955 have been nearly equalled by those added to the camp registration rolls. Even completion of two major reclamation projects-in the Sinai region and the Yarmuk-Jordan Valley -would only result in the integration of about a quarter of the refugees. ${ }^{35}$ The recent more favorable view among the Arab states toward small-scale projects is a hopeful sign, ${ }^{36}$ however, although Arab commitments are not noted for reliability.

${ }^{32}$ On Arab feudalism, see Malik, The Near East: The Search for Truth, 30 Foreicn ArF. 23r, 248 (1952).

${ }^{33}$ See How the United Nations Helps the Palestinian Refugees, 2 U. N. Rev. II (1955).

${ }^{34}$ See Relief and Works Agency for Palestine Refugees in the Near East, Annual Report of the Director, U. N. Generai Assembly OfF. Rec., gth Sess., Supp. No. 17, at I (Doc. No. A/2717) (1954).

${ }^{35}$ This estimate is based upon statements made by UNRWA officials. According to Henry $R$. Labouisse, present UNRWA director, the two projects should ultimately provide employment and settlement for about 200,000 refugees.

${ }^{30}$ The writer cannot accept the view that small-scale projects will resolve the problem most efficiently, but for a contrary view, see Peretz, The Arab Refugee Dilemma, 33 Foreign AFF. 147 (1954). 
But, as has been indicated, Moslem politics are not the sole obstacle; there are moderates among the Arab states, as there are moderates in Israel. Other barriers include the ambivalence among the refugees about repatriation, Israel's refusal to consider token repatriation which might induce the majority to remain when confronted with definite choice, and the great engineering problems involved in developing the arid Arab borderlands. Finally, though the UNRWA projects do not prejudice the ultimate issue of repatriation and compensation as defined by the Assembly, many Arab leaders use this argument to oppose an expanded program. ${ }^{37}$

That social cancer, the Arab refugee problem, can only be treated by further development of international integration programs, however numerous the roadblocks to success. Having recently turned from the sterile policy of constructing paper empires of military alliances, the American Secretary of State has suggested a sensible plan. Worked into a firm United Nations commitment, it would have the following general provisions: First, it would be tacitly agreed that Israel's legal existence could not be questioned, nor would she be expected to accept total repatriation of the refugees. Second, Israel would have to make adequate compensation for refugee property loss, costs to be partly underwritten by a long-term BritishAmerican loan. Israel would also have to offer repatriation to perhaps roo,000 refugees, with priority granted to separated families, it being understood that the refugees could expect a status no different from that enjoyed by other members of the Arab minority in Israel. The Arab refugees remaining could anticipate participation in an expanded integration program to which the United Nations, the Arab states, and Israel would contribute. International funds, now wasted on relief, could thus be diverted to both integration and partial repatriation. ${ }^{38}$ (There is speculation that, if confronted with meaningful choices in the place of empty rhetoric, most of the refugees would choose integration, with less than roo,000 opting for a return to a state which has been wholly transformed in their absence.) Arab "face" also might thus be saved on the repatriation issue. And Israel would have gone very far toward meeting a moral responsibility-for whatever the original role played by Arab demagogues in inciting the refugees to flee in 1948 , the fact remains that the refugees did lose their land and property to the new Jewish settlers. Of course, only the most sanguine would look forward to the swift adoption of the course recommended here. But some way must be found to alter the dependent, relief status of the Arab refugees.

The conditions for refugee status transition are being worked out in altogether different fashion in Israel. Since 1948 , over 700,000 immigrants have entered the new state, the majority refugees from Nazi persecution in Europe and Arab harassment in the Middle East. In the critical years after World War II, the United Nations and the world Jewish community cooperated in rescuing these groups and transporting them to Isarel. Now refugee immigration has practically ceased, save

${ }^{37}$ Cf. Relief and Works Agency for Palestine Refugees in the Near East, supra note 34 passim.

${ }^{38}$ Dulles, The Middle East, 33 Dep't State Bull. 378, 379 (1955). 
for the influx of a few thousand North African Jews. ${ }^{30}$ (There are about half a million Jews in North Africa, most of whom are expected to remain, especially if the new Moroccan and Tunisian governments implement pledges to replace the traditional Jewish status of dhummi-legal protection but not citizenship-with a grant of full equality with Moslems.)

Surely, there is contradiction in Zionism-a nationalist ideology developed to meet the problems created by nationalism-to-excess! But the lengthy debate among the Jewish intelligentsia over the wisdom of Zionism is no longer relevant. The question is academic; the resurgence of anti-Semitism in Europe, together with the indifference in the West toward the fate of the victims, converted the idea of "a homeland for Jewish national culture" into the necessity for a country of asylum. The crucial fact is that Israel has given refuge to and absorbed so many thousands of displaced and homeless Jews. And more positively, Zionism has made it possible to create in the Middle East a modern, democratic society, devoted to human freedom and, with all its faults and occasional xenophobic excesses, committed to fostering a stable Middle East. The world Jewish community outside Israel is free to reject both the naive solution proffered by Arthur Koestler and David Ben Gurion (either assimiliate completely or move to Israel), ${ }^{40}$ and the equally absurd alternative propounded by anti-Zionist American Jews (regard Israel as just one more foreign nation-state). ${ }^{41}$ Instead, American Jews and Jews elsewhere can continue to support Israel chiefly on the grounds that it is resettling refugees for whom there is no other place. This holds equally well for non-Jews who recognize an international responsibility to contribute to a solution of the refugee problem.

Since 1948, the status transition from refugee, to immigrant, to citizen, has been accelerated in Israel. The process is complicated by the fact that the proportion of newcomers to older residents is very high; by the fact that there are many so-called Oriental Jews from the backward Arab villages and towns who are being pressed to read, to write, to run machinery, to vote; by the fact that there is strain between the European and Oriental groups comparable to the tension between "old" and "new" immigrants in the United States; ${ }^{42}$ by conflict between labor socialists and orthodox rabbinical groups; by controversy over how best to cushion an adverse balance of trade. But throughout the state, the various refugee groups-from Germany, Poland, Russia, Iraq, Yemen, even India and China-are being absorbed into a dynamic social system which joins an industrial-urban complex to a traditional agricultural base. The exiles in the Diaspora are being gathered in.

IV

In 1945, the victorious Allies in western Europe established the goal of "permanent solution" of the refugee and displaced persons problem brought about by

${ }^{30}$ See TAFt and RobBins, op. cit. supra note 17, at 290-91.

10 See Arthur Koestler, Trail of the Dinosaur (1955); Teller, America's Two Zionist Traditions, 20 COMMENTARY 343 (1955).

"1 See, e.g., Alfred Lilienthal, What Price Israel? (I953).

12 See Abraham Shunsky, The Clash of Cultures in Israez (1955). 
World War II. ${ }^{43}$ If the end was never quite realized, the task accomplished was, nonetheless striking. The IRO resettlement program has already been described. What stands out in this experiment, over and above the waste motion and ineffciency, is the lesson that a planned, multilaterally organized approach to the refugee question is as feasible as it is desirable.

By the end of 1953 , however, the economic and social climate of western Europe had undergone several marked changes. Countries paralyzed by the destruction of World War II had gone far along the road to economic recovery. They had also managed to avoid further large-scale warfare on the European continent, warfare which would have meant, among other things, additional thousands of refugees. The World War II refugees had been greatly reduced in number through resettlement and reintegration, although more than 70,000 remained in camps, and several thousand additional "difficult cases" required institutional care. (These people were located not only in western Europe, but in Greece, Turkey, parts of the Middle East, and China.) Overseas countries of potential reception, somewhat fatigued by the refugee issue, felt free again to consider the "refugee emergency" within the framework of broad immigration policy. They commenced to re-examine their immigration policies in the light of the availability of "surplus peoples," persons whose status did not necessarily include a background as victims of persecution, but who might contribute to economic development overseas, and in a limited fashion, might reduce economic pressures at home. In short, in western Europe, the relation between immigrant and refugee statuses commenced to be redrawn. This difference between 1945 and 1956 , between European stabilization and Asian turmoil, between "refugee emergency" and the "surplus population problem," is borne out by a brief appraisal of actual refugee situations.

The refugees from World War II and before who remain in Europe come under the mandate of the United Nations High Commissioner for Refugees (UNHCR), Dr. G. J. Van Heuven Goedhart, who hopes to arrive at a "permanent solution" by I958. (Dr. Goedhart recognizes, however, that international disorganization is characteristic of the times, making hazardous any predictions of final settlement.) The mandate covers about 350,000 persons, of whom about 70,000 are still in camp communities or living under distressed conditions. UNHCR is concerned primarily with facilitating integration and assuring legal protection; it sponsors no resettlement except for assisting a few refugees to emigrate under the supervision of the Intergovernmental Committee for European Migration (ICEM). ${ }^{44}$ "For probably

\footnotetext{
${ }^{43}$ See Director General of the International Refugee Organization, Migration from Europe i2 (195I).

"This Committee was formed in 1951 , on American initiative. It has twenty-four member-governments, but is organized outside the United Nations to avoid affiliation with the ILO, whose membership includes Soviet satellites. It has financed, since 1952 , an annual overseas emigration of about 120,000 from Germany, Austria, Greece, Italy, and the Netherlands. The migrants have gone principally to the Unitcd States, Canada, Australia, and Latin America. While several thousands of these persons have been refugees, ICEM has focused primarily on the problem of limited emigration of "surplus peoples." Projected emigration for 1956 is about 125,000 Europeans. See Warren, International Efforts to Solve
} 
ninety per cent of the refugees now under the wing of High Commissioner's Office, assimilation among the populations of countries where they are living must be the ultimate answer to their problem." ${ }^{\text {"45 }}$ Nevertheless, UNHCR's work has been valuable, and the Nobel Peace Prize awarded to it in 1955 was certainly deserved. For clearing the camps, extending legal protection, and establishing final solutions for "difficult cases," the High Commissioner requires about $\$ 16,000,000$. Those not in need of immediate attention will move toward integration largely on their own, in various European countries. Special efforts will be made to aid several thousand Greek refugees.

The only other non-German European refugees are the East European escapees, roughly 200,000 persons who have fled Soviet-dominated areas to seek asylum in West Germany or Austria. They are mostly from Czechoslovakia and the Balkan states, but those from the Soviet Union itself receive more public attention since they represent tangible evidence of the superiority of western freedom measured against the Soviet system. Unfortunately, the West has encouraged flight from Iron Curtain countries without giving enough thought to the eventual status of those who take the risk. This has led to some disillusionment on the part of the refugees, who may now be more willing to respond to the Soviet Union's appeal to repatriate under amnesty. The United States Government as well as American private groups support the escapee program. The escapees are eligible for emigration overseas sponsored by the ICEM, and a small number have arrived in the United States under the terms of the Refugee Relief Act. Integration in West Germany is proceeding very slowly. The West has half-neglected this refugee group. Yet, as a New York Times editorial remarks, "The challenge and our responsibility to meet it would seem plain."46

West Germany's refugee problem, which loomed so large in the early postwar years, is now being resolved through integration. Altogether, about ten million persons are included in the total: ethnic Germans, Germans expelled from former territory of the Reich east of the Oder-Niesse line, Germans who have fled the Sovietcontrolled East German territory. The massive exodus into rump Germany not only resulted in severe social disorganization, but raised serious ethical questions discussed earlier. The point to stress here, however, is the progress made in refugee integration as a corollary of marked economic recovery. Ethnically similar to the host peoples, the expellees were granted equal legal status soon after their arrival. Camp populations were drastically reduced, refugee unemployment rates were cut (though not to the level of the domestic labor force), and a more even refugee regional distribution achieved. Overseas resettlement never figured seriously in the plans for absorption; West Germany was short of labor herself, and, in addition,

Refugee Problems, 30 Dep'T StATE BuLl. 26 (1954), for a deseription of the organization of ICEM and a summary of its progress over a two-year period.

${ }^{25}$ Dep't of Public Information, Promoting Permanent Solutions for Rigugees, An Internatronal Community Program 5 (U. N. Pub. Sales No. 1954.1.18).

${ }^{46} \mathrm{~N}$. Y. Times, Jan. 25, 1956, p. 30, col. 3 . 
overseas political hostility toward Germans remained a potent force for several years. Today, it is estimated that over three-fourths of the refugees are integrated. (The rough percentage, an unreliable index admittedly, is measured in terms of employment, housing, social security.) Although integration is being accomplished without support from international organizations, it would be wrong to suppose that West Germany received no assistance from abroad. Direct American aid to refugees was channeled through the ECA/MSA program, while refugees shared indirectly in the billion dollars appropriated by Congress through 1952 for West Germany and Berlin. ${ }^{47}$

Other things being equal, expellee integration and social assimilation should be realized by the end of this decade. Reunification of Germany-a doubtful prospect at present-would, of course, have an impact on the refugee problem. Conceivably, the Soviet Union might then permit a partial repatriation of Germans to the eastern territories if new accords could be written with the Polish Government.

In brief compass, this is the picture of the refugee situation at the present time in Europe, the Middle East, and Asia. In Europe, the United Nations and individual nation-states have succeeded in resettling or integrating large numbers of refugees, leaving a smaller group whose uncertain status still commands mora! sympathy and may yet call out an international response sufficient to assure "final settlement." As a result, European members of the Free World are now turning" their attention to economic development, including the possibility of sponsoring limited emigration, nonrefugee and refugee, in order to cope with labor surpluses. On the other hand, for refugee groups in the Middle East and Asia, reintegration is far from achieved, while resettlement overseas is largely an academic question. The West recognizes that it shares with governments directly concerned some responsibility for this state of affairs. But ethical concern is tempered with realism. Even a marked increase in western aid to underdeveloped regions could not dissolve problems of economic distress, overpopulation, and nationalistic conflict which underlie the refugee issue. What aid and trade may do, however, is to hasten currents of economic and social change. Along this general route lies the opportunity to improve the special status of thousands of Asian and near eastern refugees.

\section{$\mathrm{V}$}

We return, at last, to the question of American immigration policy and its relation to the refugee problem. As indicated previously, the United States has played an important part in the program to assist populations displaced by war or political action. Our contribution to status transition is represented by the more than 400,000 refugees and displaced persons resettled here since the end of World War II. There is every reason to believe that this group will successfully assimilate within the framework of a pluralistic culture. And the difficulties faced by the present

${ }^{47}$ For a summary review, see Schechtman, Postwar Population Transfers in Europe: A Study, I5 Review of Politics I5I (1953). See also Friedrich Erding, The Refugees as a Burden, a Stmiulus, and a Challenge to the West German Economy (I95I). 
refugee-immigrants seem no more severe than those encountered by earlier voluntary immigrants or the refugees of the thirties. ${ }^{48}$

With respect to international organization, this country supports the work of the High Commissioner, contributes more than any other nation-state to UNRWA's relief projects for Arab refugees, upholds the principles of legal protection contained in the Refugee Convention, and, through its general foreign-aid programs, indirectly assists countries whose problems are complicated by the presence of large refugee groups. It can be argued, however, that we may better discharge our international responsibilities in two additional ways. First, our moral commitment to sustain principles of justice in the treatment of displaced populations would have greater force if this government became a party to the Convention on Genocide as well as the agreement to oppose various kinds of forced labor. (We also have a clear obligation to sign and ratify the Convention on the Status of Refugees to which fourteen states are parties.) For, it is clear that refugees are often the product of decisions by dictatorial regimes to engage in mass extermination of minority peoples or to deport workers by the thousands to distant territories to work as modern slaves. In an effort to appease the proponents of the Bricker Amendment, the Secretary of State appears to have been reluctant to enter into these commitments. He has said that our own national law already guarantees individuals and groups against such abuses. All the more reason, then, it would seem, to place our moral position squarely on record; nothing is lost in the way of national sovereignty, something is gained in supporting international agreements. Second, the leading nationstates in the West, the United States included, could readily sustain an IRO on a smaller scale than the IRO of the postwar period but committed to the same general ends. It is apparent that the present High Commissioner's Office is too restricted in scope and geographic mandate. A new IRO-indeed, a permanent IRO-would constitute international recognition of the endless challenge posed by refugee problems. If properly organized to avoid overbureaucratization, if properly designed to steer a firm path between international obligations and national interest, if animated by the desire to include limited numbers of Asian and Middle Eastern as well as European refugees in plans for resettlement-such an organization would materially strengthen the constructive side of the United Nations' work.

In the United States itself, the primary task lies, as already noted, in bringing greater flexibility to the immigrant-refugee relationship. This can be accomplished largely by reappraising the national-origins quota system. Given the present coalition of interest groups in Congress, the proposal of the President's Commission on Immigration and Naturalization to assign a bloc of quota visas to refugees without regard to national origin ${ }^{49}$ is not likely to realized. (The proposal called for the admission of these persons under a special category based on the right of asylum.) A more realistic alternative is to adopt, as soon as possible, necessary revisions of

\footnotetext{
${ }^{48}$ See generally U. S. Displaced Persons Comom's, op. cit. supra note 6.

10 President's Comm'n on Immigration and Naturalization, op. cit. supra note 4, at ir8-ig.
} 
our immigration law within the national-origins framework. Over-all quota immigration should be increased by roo,000 visas to a total of about 254,000; this would permit refugees-and nonrefugees-to emigrate in larger numbers from countries with tiny quotas. The mortgage on future quotas, brought about by the displaced persons program of $1948-52$, represents a legislative quirk which should be eliminated. Provision should be made for pooling unused quotas which accumulate yearly from western European countries. Assignment of these visas can be made to immigrants with special preferences and to a limited number of refugees seeking asylum, regardless of place of origin. Finally, coordination between immigration and refugee policy is a complex matter; it should be the responsibility of an administrator skilled in treating immigration problems, not the responsibility of a security officer in the State Department. Obviously, refugee admissions must be cleared on security grounds, but this scarcely means that the obverse holds-that security matters should determine refugee admission policy. The Refugee Relief Act is a telling example of this confusion.

These are the minimum requirements of a revised refugee policy. ${ }^{50}$ No one is prepared to defend the right of asylum in absolute terms. The United States could not open its doors to all those seeking a haven from oppression overseas, even if the Congress were so minded. But there is an urgent necessity to alter the most restrictive aspects of a most restrictive law-the McCarran-Walter Act-so as to admit additional refugee-immigrants, to offer asylum, in Washington's phrase, to "the oppressed and persecuted of all Nations and Religion; whom we shall welcome to a participation of all our rights and privileges, if by decency and propriety of conduct they appear to merit the enjoyment."51

\footnotetext{
${ }^{50}$ These recommendations are embodied in a statement which the writer submitted to the Subcommittee of the Committee of the Judiciary studying revision of the immigration laws, in November 1955. They were submitted in the form of a statement to the subcommittee and entered into the record. On Feb. 8, 1956, President Eisenhower submitted a special message on immigration to Congress, recommending an increase in quotas of about 65,000 , elimination of the displaced persons mortgage, and the pooling of unused quotas without regard to national origin (but, unfortunately, also without regard to a category of asylum among the preferences to be carried over from existing law). Immigration and Nationality Laws, H. Doc. No. 329, 84th Cong., 2d Sess. (1956).

${ }^{21} 27$ The Writings of George Washington 254 (Fitzpatrick ed. 1938".
} 